\title{
ECMO in paediatric septic shock: an urgent need for prospective trial
}

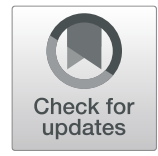

\author{
Xavier Beretta-Piccoli', Dominique Biarent ${ }^{1}$, David De Bels ${ }^{2}$, Patrick M. Honore ${ }^{2}$ and Sébastien Redant ${ }^{12^{*}}$ (D)
}

The publication by Schlapbach et al. used a sepsis mortality prediction model to define a mortality threshold above which patients suffering from septic shock could benefit from venoarterial ECMO (VA-ECMO). When predicted mortality was lower than $47.1 \%$, the measured mortality was $11.8 \%$ higher, while when the predicted mortality was higher than $47.1 \%$, the measured mortality was $16.2 \%$ lower. Seventy-one per cent of patients were cannulated centrally with a central flow significantly higher than peripheral ECMO (173 versus $129 \mathrm{ml} / \mathrm{kg} / \mathrm{min}, p<0.05$ ) [1]. However, central techniques are not available everywhere, and percutaneous VA-ECMO technique is spreading and frequently done by intensivists but does not allow flow as high as those described by Schlapbach. We were surprised by the benefit brought by central cannulation on survival in the multivariate analysis $(p=0.046)$ while higher flows did not reach significance on survival nor in the uni- $(p=0.27)$ nor in the multivariate analyses $(p=\mathrm{NS})$. Other studies in paediatric septic shock have shown a survival benefit from ECMO flow rates greater than $150 \mathrm{ml} / \mathrm{kg} / \mathrm{min}$ [2].

The mortality score developed for the study is simple and practical. However, it does not distinguish between the different haemodynamic profiles seen in paediatric shock.
More than $50 \%$ of children with septic shock have cold clamped extremities, low cardiac output and elevated vascular resistance [3]. VA-ECMO in this profile may restore cardiac output hence improving haemodynamics. The debate remains open in high cardiac output shock where the native heart delivers a flow greater than the maximal peripheral ECMO flow. The guidelines recommend VAECMO in refractory shock with a special attention to the cardiac index. When it is less than $3.3 \mathrm{l} / \mathrm{min} / \mathrm{m}^{2}$, optimizing inotropes should be first considered before ECMO [4].

As proposed by the authors, prospective studies are necessary, and we suggest to include ultrasound values such as the cardiac index, the systemic vascular resistance index and the velocity time integral [5]. Even if it has been shown that these parameters are not interpretable on admission because they are preload-dependent, once the active filling phase has been completed, the echocardiography is a tool which enables the practitioner to be informed on the exact haemodynamic profile of the child [5]. The question that a prospective study should answer is whether a particular haemodynamic profile will better answer to VA-ECMO and accordingly which ECMO flow will be appropriate. 


\title{
Authors' response
}

\author{
Luregn J Schlapbach ${ }^{1,2,3}$, Warwick Butt ${ }^{4}$, Graeme MacLaren ${ }^{4,5}$ on behalf of the Australian \& New Zealand Intensive Care \\ Society (ANZICS) Paediatric Study Group \\ 1Paediatric Critical Care Research Group, Child Health Research Centre, The University of Queensland, Brisbane, Australia \\ ${ }^{2}$ Paediatric Intensive Care Unit, Queensland Children's Hospital, Brisbane, Australia \\ ${ }^{3}$ Department of Intensive Care Medicine and Neonatology, and Children's Research Center, University Children's Hospital \\ of Zurich, University of Zurich, Zurich, Switzerland \\ ${ }^{4}$ Paediatric Intensive Care Unit, The Royal Children's Hospital, Melbourne, Australia \\ ${ }^{5}$ Cardiothoracic Intensive Care Unit, National University Health System, Singapore, Singapore
}

We thank Beretta-Piccoli and colleagues for their comment regarding our study defining benefit thresholds for ECMO in children with septic shock [1]. The 2020 Pediatric Surviving Sepsis Campaign [6] guidelines issued a recommendation based on low-quality evidence for venoarterial ECMO as rescue therapy for septic shock "refractory to all other treatments". The problem is when to consider shock "refractory" [7]. The mortality in refractory shock even without ECMO is not $100 \%$, and clinicians have to weigh risk versus benefit of ECMO. While every day clinical decision-making embraces implicit or explicit benefit threshold estimates, our study provides one of the first objective approaches to this scenario.

The first point raised by Beretta-Piccoli et al. relates to the generalizability of the findings, given that central cannulation was the predominant access used in our study. Central cannulation provides higher flows and maintains bilateral carotid perfusion with potentially lower cerebral stroke incidence at the expense of higher overall bleeding and infection risk. While central ECMO currently is limited to cardiosurgical centres, these complications are manageable, and timely referral to such high-volume centres should be emphasized.

The second point makes reference to the fact that the Paediatric Sepsis Score [8] used in the study provides no direct measure of the haemodynamic pattern. Yet, cold shock or warm shock, respectively, are not fixed entities but rather reflect a dynamic process: Septic children often move from hyperdynamic states with variable systemic vascular resistance to progressive cardiogenic shock. Regardless of the pattern, ECMO with appropriate flows can reverse the deficit in oxygen delivery to tissues. Sequential rather than single assessment of the Sepsis Score may improve discrimination on children on a trajectory towards cardiac arrest and irreversible organ damage.

Finally, Beretta-Piccoli et al. propose an ultrasoundbased study assessing haemodynamic profiles to assist in decisions on ECMO initiation and to tailor the cannulation strategy based on the required flows. We concur that repeated echocardiographic assessment of cardiac function should be routinely performed. Accurate and rapid assessment can improve the timeliness of cannulation. Although the highest ECMO benefit was observed in children post-cardiac arrest, clinicians should endeavour to recognize impending cardiac arrest prior to its occurrence [2].

In summary, although decisions on whether to place a child with sepsis on ECMO may always happen on an individual basis, such should not prevent us from applying benefit threshold estimates to assess the appropriateness of such decisions-similar to most areas of critical care where risk-adjusted benchmarking has been the standard for decades [9].

\section{Abbreviations}

VA-ECMO: Venoarterial ECMO

\section{Acknowledgements}

None.

\section{Authors' contributions}

XBP, DB and SR designed the paper. All authors participated in the drafting and review. All authors read and approved the final version of the manuscript.

\section{Funding}

None.

\section{Availability of data and materials Not applicable.}

Ethics approval and consent to participate

Not applicable.

Consent for publication

Not applicable.

Competing interests

The authors declare that they have no competing interests.

Received: 21 January 2020 Accepted: 14 February 2020

Published online: 12 March 2020

\section{References}

1. Schlapbach LJ, Chiletti R, Straney L, Festa M, Alexander D, Butt W, et al. Defining benefit threshold for extracorporeal membrane oxygenation in 
children with sepsis-a binational multicenter cohort study. Crit Care. 2019; 23(1):429. https://doi.org/10.1186/s13054-019-2685-1.

2. Oberender F, Ganeshalingham A, Fortenberry JD, Hobson MJ, Houmes RJ, Morris KP, et al. Venoarterial extracorporeal membrane oxygenation versus conventional therapy in severe pediatric septic shock. Pediatr Crit Care Med. 2018;19(10):965-72. https://doi.org/10.1097/PCC.0000000000001660.

3. Aneja RK, Carcillo JA. Differences between adult and pediatric septic shock. Minerva Anestesiol. 2011;77(10):986-92.

4. Davis AL, Carcillo JA, Aneja RK, Deymann AJ, Lin JC, Nguyen TC, et al. The American College of Critical Care Medicine clinical practice rarameters for hemodynamic support of pediatric and neonatal septic shock: executive summary. Pediatr Crit Care Med. 2017;18(9):884-90. https://doi.org/10.1097/ PCC.0000000000001259.

5. Abdalaziz FA, Algebaly HAF, Ismail RI, El-Sherbini SA, Behairy A. The use of bedside echocardiography for measuring cardiac index and systemic vascular resistance in pediatric patients with septic shock. Rev Bras Ter Intensiva. 2018;30(4):460-70. https://doi.org/10.5935/0103-507X.20180067.

6. Weiss SL, Peters MJ, Alhazzani W, Agus MSD, Flori HR, Inwald DP, Nadel S, Schlapbach LJ, Tasker RC, Argent AC, et al. Surviving sepsis campaign international guidelines for the management of septic shock and sepsisassociated organ dysfunction in children. Intensive Care Med. 2020; 46(Suppl 1):10-67.

7. Morin L, Ray S, Wilson C, Remy S, Benissa MR, Jansen NJG, Javouhey E, Peters MJ, Kneyber M, De Luca D, et al. Refractory septic shock in children: a European Society of Paediatric and Neonatal Intensive Care definition. Intensive Care Med. 2016;42(12):1948-57.

8. Schlapbach LJ, MacLaren G, Festa M, Alexander J, Erickson S, Beca J, Slater A, Schibler A, Pilcher D, Millar J, et al. Prediction of pediatric sepsis mortality within $1 \mathrm{~h}$ of intensive care admission. Intensive Care Med. 2017;43(8):1085-96.

9. MacLaren G, Cho HJ, Schlapbach LJ. Transforming Data Into a Crystal BallPredicting Outcomes After Extracorporeal Membrane Oxygenation. Pediatr Crit Care Med. 2019;20(5):490-91.

\section{Publisher's Note}

Springer Nature remains neutral with regard to jurisdictional claims in published maps and institutional affiliations. 